\title{
It's (Change in) the (Future) Economy, Stupid: Economic Indicators, the Media, and Public Opinion
}

\author{
Stuart N. Soroka University of Michigan \\ Dominik A. Stecula University of British Columbia \\ Christopher Wlezien University of Texas at Austin
}

\begin{abstract}
Economic perceptions affect policy preferences and government support. It thus matters that these perceptions are driven by factors other than the economy, including media coverage. We nevertheless know little about how media reflect economic trends, and whether they influence (or are influenced by) public economic perceptions. This article explores the economy, media, and public opinion, focusing in particular on whether media coverage and the public react to changes in or levels of economic activity, and the past, present, or future economy. Analyses rely on content-analytic data drawn from 30,000 news stories over 30 years in the United States. Results indicate that coverage reflects change in the future economy, and that this both influences and is influenced by public evaluations. These patterns make more understandable the somewhat surprising finding of positive coverage and public assessments in the midst of the Great Recession. They also may help explain previous findings in political behavior.
\end{abstract}

A growing body of work demonstrates a link between economic conditions and both attitudes about government policy and preferences for spending (e.g., Durr 1993; Erikson, MacKuen, and Stimson 2002; Soroka and Wlezien 2010; Stevenson 2001; Wlezien 1995). There also are vast literatures exploring the degree to which support for governments and leaders follows economic trends. Some work focuses on economic conditions and assessments of presidential/government performance and voting (e.g., Bartels and Zaller 2001; Campbell 1996; Clarke and Stewart 1995; Erikson 1989; Happy 1986; Hibbs 1987; MacKuen, Erikson, and Stimson 1992; Nadeau, Niemi, and Amato 1994, 1996; Nadeau et al. 1999; Price and Sanders 1993; Sanders 1996, 1999; Sanders, Marsh, and Ward
1993; for reviews, see Lewis-Beck and Stegmaier 2000, 2007); a related body of research uses key economic variables to predict - with a good degree of success - the outcome of elections, both in the United States and elsewhere (e.g., Abramowitz 1988; Erikson and Wlezien 2012; Lewis-Beck 1988b; Wlezien and Erikson 1996; for recent reviews, see Kayser and Wlezien 2011; Linn, Nagler, and Morales 2010). There is, in sum, a considerable body of evidence highlighting the political importance of economic conditions.

Public perceptions of the economy matter as well. In fact, past work suggests that economic perceptions influence vote intentions and government evaluations above and beyond the impact of the actual economy (e.g., Nadeau, Niemi, and Amato 1994). The sources of

Stuart N. Soroka is Professor of Communication Studies and Political Science, and Faculty Associate at the Center for Political Studies, Institute for Social Research, University of Michigan, 5370 North Quad, 105 South State Street, Ann Arbor, MI 48109-1285 (ssoroka@umich.edu). Dominik A. Stecula is a Ph.D. student, Department of Political Science, University of British Columbia, C425 - 1866 Main Mall, Vancouver, British Columbia V6T 1Z1 (d.stecula@alumni.ubc.ca). Christopher Wlezien is Hogg Professor of Government, Department of Government, University of Texas at Austin, Batts Hall, Austin, TX 78712-1704 (wlezien@austin.utexas.edu).

Previous versions of this article were presented at the 68th Annual Conference of the American Association for Public Opinion Research, Boston, May 2013, and the 71st Annual Conference of the Midwest Political Science Association, Chicago, April 2013. We are grateful to Stephen Farnsworth and J. Scott Matthews for helpful advice along the way, to Brian J. Fogarty for comments on a previous draft, to Ataman Ozyildirim for help with Conference Board indicators, and to Lori Young for her work on the Lexicoder Sentiment Dictionary. Partial support for this research was provided by the Fonds de recherche sur la société et la culture, Quebec, Canada. The data used in this study, as well as a do-file replicating all the results, are available directly from the authors at snsoroka.com, as well as in the AJPS Data Archive on Dataverse (http://dvn.iq.harvard.edu/dvn/dv/ajps).

American Journal of Political Science, Vol. 59, No. 2, April 2015, Pp. 457-474

(C) 2014, Midwest Political Science Association

DOI: 10.1111/ajps.12145

This is an open access article under the terms of the Creative Commons Attribution License, which permits use, distribution and reproduction in any medium, provided the original work is properly cited. 
public perceptions of the economy are nevertheless not well understood. For instance, although research suggests that media coverage can affect public economic perceptions (e.g., De Boef and Kellstedt 2004; Nadeau et al. 1999; Soroka 2006, 2014), ${ }^{1}$ we have only a partial understanding of what causes that coverage. The real economy surely plays a role; it is not well understood how. It also is not clear whether and how public economic perceptions themselves impact coverage. This article seeks to redress this imbalance.

The central contribution here is an investigation of two absolutely critical but underappreciated aspects of the media-economy-opinion nexus. First, we consider the possibility that both media and public opinion react more to changes than the levels in economic conditions. They may not react to high unemployment so much as an increase in the rate, for instance. Second, we consider whether the media and the public respond to the past, present, or future economy. They may not react to where we have been as much as where we are; but it also may be that media react mostly to where we are going. Indeed, media may also react in part not just to the economy, but also to public perceptions of the economy; that is, media content may partly reflect where the public thinks the economy is going.

Some of these possibilities have been explored in part in existing political behavioral research, which we discuss in greater detail in the following section. The relative impact of changes versus levels in the future versus the past and present economy has received very little attention in the literature focused on media content, however. This is true in spite of the fact that the ways in which mass media register and convey economic information may provide valuable insights relevant to our understanding of political behavior. Indeed, in addition to better understanding the ways in which the economy becomes "news," one objective here is to see whether media content mirrors, and perhaps even helps explain, existing political-behavioral findings.

The article begins with a review of the literature on the relationship between the economy, economic news, and public perceptions. We then introduce and analyze our data: content-analytic results from nearly 30,000 news stories over 20 years in the United States, alongside measures of the economy and public economic sentiment. We explore the relationship between media content and the economy, and then turn to aggregate-level trends in public opinion. Results speak to the nature of the

${ }^{1}$ Also see, for example, work on the impact of presidential rhetoric by Wood, Owens, and Durham (2005). relationship between the economy, economic news, and public sentiment; in particular, they make clear the extent to which media stories (and media effects) are driven by short-term changes, rather than long-term levels, of economic indicators. It appears that both the media and the public are particularly responsive to where the economy is going in the future, in addition to-and at least sometimes more than-where it has been or currently is. As we shall see, this has consequences for public assessments of the economy, which themselves also affect media coverage. All of this matters, we believe, for the way in which the economy matters for political behavior.

\section{The Economy, Economic News, and Economic Perceptions}

The literature focused directly on media coverage of the economy is relatively small, but there is a considerable body of work focused on the impact that this media coverage may have on public opinion. This research makes clear that there are close relationships between the condition of the economy, the media's portrayal of this condition, and people's opinions about the economy. Put simply: The media play an important role in shaping public opinion about the economy. This has been well established in the literatures on public opinion and political communication (e.g., Blood and Phillips 1995, 1997; Boomgaarden et al. 2011; De Boef and Kellstedt 2004; Glynn, Huge, and Hoffman 2008; Goidel et al. 2010); it has been illustrated in work by economists as well (e.g., Carroll 2003; Doms and Morin 2004; Hollanders and Vliegenthart 2011). Additionally, the political importance of the effects of media coverage on public opinion is made readily clear in the literatures (cited above) on policy preferences and economic voting.

Existing research tends to focus on either the (a) volume or (b) tone of media coverage. It may be that both play important-and distinct-roles in the mediaopinion relationship, however. Consider work suggesting that, since gathering and processing information about the economy is costly, people do not continuously update their expectations but rather do so only occasionally and remain largely inattentive in between (e.g., Carroll 2003 and Doepke et al. 2008, both of which suggest that updating may occur less than once a year). Expectation updating, according to this work, occurs when there are high volumes of economic news, and economic news tends to be most frequent when the economy is bad (e.g., Doms 
and Morin 2004; Lamla and Lein 2008; Shah et al. 1999). ${ }^{2}$ It follows that individuals' expectations may be a product not just of media tone, but of the volume of coverage as well, which may often serve to augment the impact of negative tone.

We explore effects of both volume and tone below. Additionally, we provide a much more detailed discussion of measures of tone and volume in Appendix A in the supporting information. For now, what is most important is that both may matter for public perceptions, above and beyond economic conditions. This is because media content is not just a reflection of economic conditions. There are a variety of differences between the economy and media coverage of the economy across both time and media outlets, and there is a growing body of work making this fact increasingly clear (see discussion below). There is relatively little work speaking to the nature of the difference, however. ${ }^{3}$ This is disconcerting given the potentially important implications of discrepancies between the real economy and economic news.

The literature points to what appear to be striking instances of such discrepancies. One relatively well-known example (noted by Lipset 1993, among others) is from the 1992 U.S. election: The argument is that President Bush lost his reelection bid not on the basis of the actual state of the economy, but due to people's perceptions of the state of the economy, which were driven by overtly negative economic coverage. It is this election that produced the phrase "It's the economy, stupid," attributed to Clinton strategist James Carville and meant to be the Clinton campaign's primary message. (This, of course, is the phrase that led to the title of the current article.) The aim was to highlight what was then still a faltering economy in an effort to encourage voters to reject Bush and support Clinton instead. Research highlights the importance of economic perceptions in that election (e.g., Alvarez and Nagler 1995), and research on other elections provides some supporting evidence. (See work that predicts U.S. election outcomes using measures of economic perceptions; e.g., Holbrook 1994.) In fact, perceptions of

\footnotetext{
${ }^{2}$ Indeed, media generally tend to focus on "problems"; see, for example, Altheide (1997) and Bennett (1997).

${ }^{3}$ There are some important exceptions, however. Fogarty (2005) examines the connection between various economic indicators and New York Times front-page coverage. Goidel et al. (2010) explore the relationship between various media sources (local and national newspapers and TV broadcasts) and the economy (as well as opinion). Harrington (1989) examines the degree to which network news focuses on negative information, contrasting election and nonelection years. Farnsworth and Lichter $(2006,2011)$ examine variation in media coverage of presidents on a range of issues, including the economy. Also see work listed in Appendix D in the supporting information.
}

the economy can matter more than objective conditions for citizens' political judgments (e.g., Sanders 2000); it also appears that media coverage can distort perceptions, at least to some degree, including in 1992 (Hetherington 1996).

What drives the gap between media content and reality? One account, which we discuss further in the following section, stresses the significance of "biases" in media gatekeeping and news production. Another variant, and one that we want to emphasize here, is that the economy is large and complex, and can be described and reflected in many different ways, and media content tends to capture certain elements of the economy more systematically than others. Past work has demonstrated a tendency for media to focus more on negative than on positive information (e.g., Soroka 2006, 2012, 2014), for instance. Here we want to examine other elements of the economy on which both media content and public economic sentiment tend to be focused.

\section{The Focus of Media Coverage}

Our examination focuses on two aspects of the mediaeconomy relationship. First, we examine whether the media coverage reflects changes in the economy alongside, if not entirely instead of, levels. Second, we assess whether coverage responds to the economic past, present, or future.

\section{Changes versus Levels}

The idea that change matters to media coverage is not new, although it has not been examined in much detail where aggregate trends in media content are concerned. The emphasis is clear in the general literature on journalistic practices, however. There is a body of work suggesting that journalistic norms lead to systematic patterns in news content (e.g., Bennett 1997; Meyrowitz 1994; Shoemaker and Vos 2009).

More specifically, research on journalistic practices makes clear the significance of novelty and change in the selection of news stories. Thomas Patterson (1994, 60) writes that "above all else, reporters are taught to search what is new and different in events of the past twenty-four hours." Election campaigns are particularly attractive to journalists, for instance, because they provide a constantly shifting set of topics and characters (e.g., Skewes 2007; see also a review of the "game" frame in Aalberg, Strömbäck, and de Vreese 2012). Discussions of ongoing, often longstanding, political issues systematically get less coverage 
than whatever new topics arise. ${ }^{4}$ Novelty and change are defining features of newsworthiness. ${ }^{5}$

Studies of the actual content of news stories highlight similar themes. There is a growing body of work focused on how the newsroom priorities of timeliness and novelty tend to reduce coverage of longer-term processes, for instance. This has been an emphasis in work on science reporting in particular, especially on environmental issues (e.g., Boykoff and Boykoff 2007; Mazur 2009; Mazur and Lee 1997; McComas and Shanahan 1999; McCright and Dunlap 2003; Soroka et al. 2012; Trumbo 1995).

But one does not need to look to very long-term processes to see the priority that novelty has in news gatekeeping; for example, media coverage of campaign-period polls increases with poll volatility (Matthews, Pickup, and Cutler 2012). There is, of course, no reason to believe that this tendency is evident only in science news or coverage of pre-election polls.

Journalists are not working in a vacuum-they are writing to appeal to an audience. So it should come as no surprise that research in political behavior points to the importance of changes in conditions where public perceptions are concerned as well. For instance, research on election outcomes reveals that voters reward and punish incumbents mostly on the basis of economic change. There is an especially long history of such research on U.S. presidential elections, where scholars using different economic measures all demonstrate that incumbent support depends on the "slope" of the economythe direction and magnitude of economic change-not the level per se (Abramowitz 1988; Bartels and Zaller 2001; Campbell 1996; Hibbs 1987; Wlezien and Erikson 1996). Importantly, this work also shows that economic change closer to the election matters more to voters than earlier economic change. ${ }^{6}$ Much the same is true for government approval between elections (especially

\footnotetext{
4 "The first time that a candidate takes a position on a key issue, the press is almost certain to report. Further statements on the same issue become progressively less newsworthy, unless a new wrinkle is added" (Patterson 1994, 61).

${ }^{5}$ The literature on this issue is vast. See, for example, Farnsworth and Lichter (2006), Jamieson (1992), Robinson and Sheehan (1983), and Davis (1992). Also see Klein's (2010) related commentary on journalism and Fuller (2010), who links the journalistic pursuit of novelty to humans' evolutionarily advantageous tendency to be especially attentive to new information.

${ }^{6}$ This is important because the Election Day outcome is not a simple sum of changes over the course of the term, which would imply that the level of the economy is determining.
}

see Erikson, MacKuen, and Stimson 2002); ${ }^{7}$ comparative research is also confirming (see, e.g., Anderson and Wlezien 1997; Clarke and Stewart 1995; Kayser and Wlezien 2011; Van Der Brug, Van Der Eijk, and Franklin 2007).

\section{The Past, Current, or Future Economy}

We are also interested in the time horizon of the economic conditions reflected in media content. Specifically, we are interested in the possibility that media content focuses more on prospective than on current or retrospective economic conditions. Work in political behavior has considered this issue-the distinction in that literature is between naive voters who can base votes only on past conditions versus sophisticated voters who are able to take forward projections into account. Research initially focused largely on the former possibility, although a literature on the latter has also accumulated (for reviews, see Lewis-Beck and Stegmaier 2000, 2007; Singer and Carlin 2013). There is, for instance, a considerable body of work suggesting that voters are driven in part by prospective evaluations (e.g., Fiorina 1981; Kuklinski and West 1981; Lewis-Beck 1988a; Lockerbie 1991); the same appears to be true for trends in both presidential approval (Chappell \& Keech 1985; MacKuen, Erikson, and Stimson 1992) and "most important problem" responses (Wlezien 2005) as well. In sum, to borrow MacKuen, Erikson, and Stimson's (1992) terminology, voters sometimes appear to behave more like (prospectively focused) bankers than (retrospectively focused) peasants.

The work by MacKuen, Erikson, and Stimson (1992) is particularly relevant here. Their primary focus is on the interplay between the economy, consumer sentiment (both retrospective and prospective), and presidential evaluations. In accounting for consumer sentiment, however, they add trends in a set of survey questions asking whether respondents have heard any "favorable or unfavorable" news about business conditions. The measure is strongly related to economic expectations, a signal that media content may be rather forward-looking.

These authors do not directly examine economic effects on media content, however, and there have been, to our knowledge, no serious considerations of the relative weight of past, current, and future economic conditions in shaping economic news. Analyses of media coverage of economic conditions tend to focus on the relationship between media coverage and a single indicator of

\footnotetext{
${ }^{7}$ The effects on approval are a bit less obvious, as changes in the economy impact changes in approval, which tend to decay over time.
} 
economic conditions-sometimes prospective, although typically not. In fact, the existing media-focused literature does not directly test the relative importance of levels or changes either. For more detailed information, Appendix $\mathrm{D}$ in the supporting information provides a list of recent studies of media content on the economy, noting decisions regarding levels versus changes, and past, present, or future economic measures.

Given work on (a) the potential importance of economic sentiment to political behavior and (b) the potential importance of media content to economic sentiment, we see this as an important gap in the literature. We thus consider here whether media focus more on future than on current and past economic conditions. In doing so, we may be one step closer to accounting for the relative importance of prospective evaluations in political judgments - the future economy matters in part because this is what media content is focused on.

\section{The Data}

We rely on three bodies of data: macroeconomic measures, media data, and measures of public opinion. We focus here on monthly time series, from 1980 to 2011 inclusive. Macroeconomic data for the United States are drawn from the Conference Board's economic indicators series. ${ }^{8}$ These allow us to assess whether media content is most reflective of past, current, or future economic conditions, by using their lagging, coincident, and leading economic indicators. The time series for the period between January 1980, and December 2011 are displayed in Figure 1.

The Lagging and Coincident Indicators in the figure are exactly as they are distributed by the Conference Board. ${ }^{9}$ We use a slightly revised version of the leading indicators series, however. Leading indicators normally include a measure of consumer sentiment. We want to look at the relationship between media, the economy, and public opinion, however, and doing so requires

${ }^{8}$ Conference Board composite indicator series were initially obtained from the Thomson Reuters Datastream financial database. The revised leading economic indicators series we use below was obtained directly from the Conference Board.

${ }^{9}$ We detrend each of the Conference Board series using a HodrickPrescott filter (Hodrick and Prescott 1997). This is the same procedure the OECD uses to detrend their own leading indicators. The main effect of detrending in this way is removing the slow upward trend in indicators over the last 40 years. That said, using the raw series makes little difference to the analyses that follow, results relating to which are available upon request. economic measures that do not include (at least not directly) public opinion itself. For this reason, we use a Conference Board measure of leading indicators purged of consumer sentiment. ${ }^{10}$ The original and revised series are very highly correlated-based on monthly data spanning 1980 to 2013, they are correlated in levels at .986 and in monthly changes at .976. (Also see Figure 1, which includes both series, the differences between which are almost imperceptible.) Even so, we proceed with the new measure knowing that analyses will not suffer from measure-induced endogeneity.

Given our interest in the relative importance of past, current, and future economic trends, the capacity of Conference Board indices to adequately capture each is of real importance. They are designed for precisely this purpose, of course; we can in part rely on the Conference Board's own research on the matter (see, e.g., Conference Board 2001; Levanon et al. 2011). But there is also related research in economics (e.g., Rogers 1994; Stock and Watson 1989; Vaccara and Zarnowitz 1978) and even in political science (Wlezien and Erikson 1996) showing that the indicators do work (e.g., the index of leading economic indicators predicts future economic growth). Appendix C in the supporting information outlines the composition of each index in some detail and provides some diagnostic statistics of the relationship between the indices (and media content) and other macroeconomic time series. In short, there is good evidence that the indices capture past, present, and future economic circumstances. While the indices surely correlate over time, they also vary independently. We thus can directly assess in our empirical analysis to which component the media and/or the public respond.

Media variables are based on a comprehensive original database of economic news stories from the New York Times and the Washington Post. The stories are obtained from the Lexis-Nexis database, using a subject search designed to identify all stories dealing with major macroeconomic issues. ${ }^{11}$ Results are manually examined to confirm that each story focused only on the domestic economy

\footnotetext{
${ }^{10}$ The consumer expectations measure is simply excluded from the calculation of the index, and the remaining nine items are left at their existing weights.

${ }^{11}$ The search was designed based on an exhaustive list of Lexis-Nexis subject categories. The final search captured stories for which any of the following terms were listed as "Relevancy: Major Terms only"under (a) "Economic Conditions": Deflation, Economic Decline, Economic Depression, Economic Growth, and Economic Recovery, Inflation and Recession; under (b) "Economic Indicators": Average Earnings, Consumer Credit, Consumer Prices, Consumer Spending, Employment Rates, Existing Home Sales, Money Supply, New Home Sales, Productivity, Retail Trade Figures, Unemployment Rates, Wholesale Prices.
} 


\section{FIGURE 1 Composite Indicators in the United States, 1980-2011}

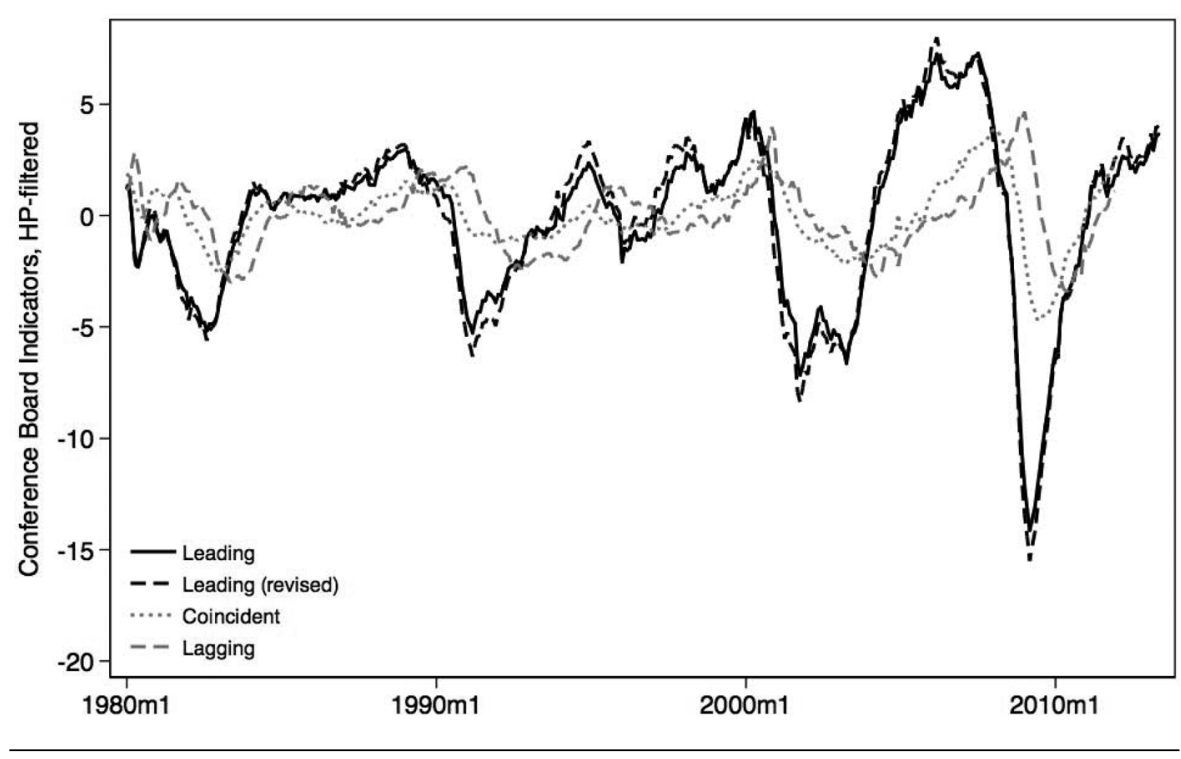

(i.e., not on the economy of other countries); irrelevant stories are eliminated. Any story of fewer than 100 words is also excluded, since these are typically short notes rather than actual newspaper articles. Economic coverage also tends to include stories that are in fact just long lists of reported economic figures and indicators; these too are eliminated. The final data set includes 31,180 stories for the two newspapers.

The next task is to convert the database of stories into time series of economic news coverage. There are, of course, several different approaches; we focus here on two different measures:

1. Volume of Coverage (Coverage): The total number of stories on the economy-a straightforward monthly article count.

2. Tone of Content (Tone): Monthly article tone, derived from Lexicoder, automated contentanalytic software using a simple bag-of-words approach to content analysis. Coding is based on the Lexicoder Sentiment Dictionary (LSD), which has already been described in some detail and tested on economic data (Young and Soroka 2012). The LSD produces counts of positive words and negative words; we use those to produce a measure of net tone using the following simple formula: (\# positive words -\# negative words)/total \# words, where the word total includes all words in the article (positive, negative, and without tone). The measure thus captures both the direction and magnitude of tone, controlling for article size. Since values tend to be relatively small, we multiply the measure by 100 below. $^{12}$

The volume and tone of coverage are illustrated in Figure 2. Note that the two series are negatively correlated, at -.22 in levels and -.14 in changes. This reflects the fact that coverage increases when the news is bad, a wellknown aspect of modern mass media (discussed above). It also suggests that while tone should be positively related to the economy and opinion, volume should be negatively related. Of course, the fact that they are weakly correlated means that there are instances when the tone is positive but volume is high, and when tone is negative while volume is low. The possibility that volume and tone interact thus seems to be worth investigating, and we do so in our analyses of public opinion below.

We want to examine the impact of both the economy and media content on public opinion as well, and we do so using consumer sentiment data from the Thomson Reuters/University of Michigan Surveys of Consumers. We focus here on two sociotropic measures of economic

\footnotetext{
${ }^{12}$ There are more sophisticated approaches to measuring tone, including the Coefficient of Imbalance (CI), one attempt to combine both volume and tone. See Appendix A in the supporting information for a discussion of the CI measure, alongside other considerations in the measurement of tone in media content.
} 


\section{FIGURE 2 The Volume and Tone of Economic News Coverage}
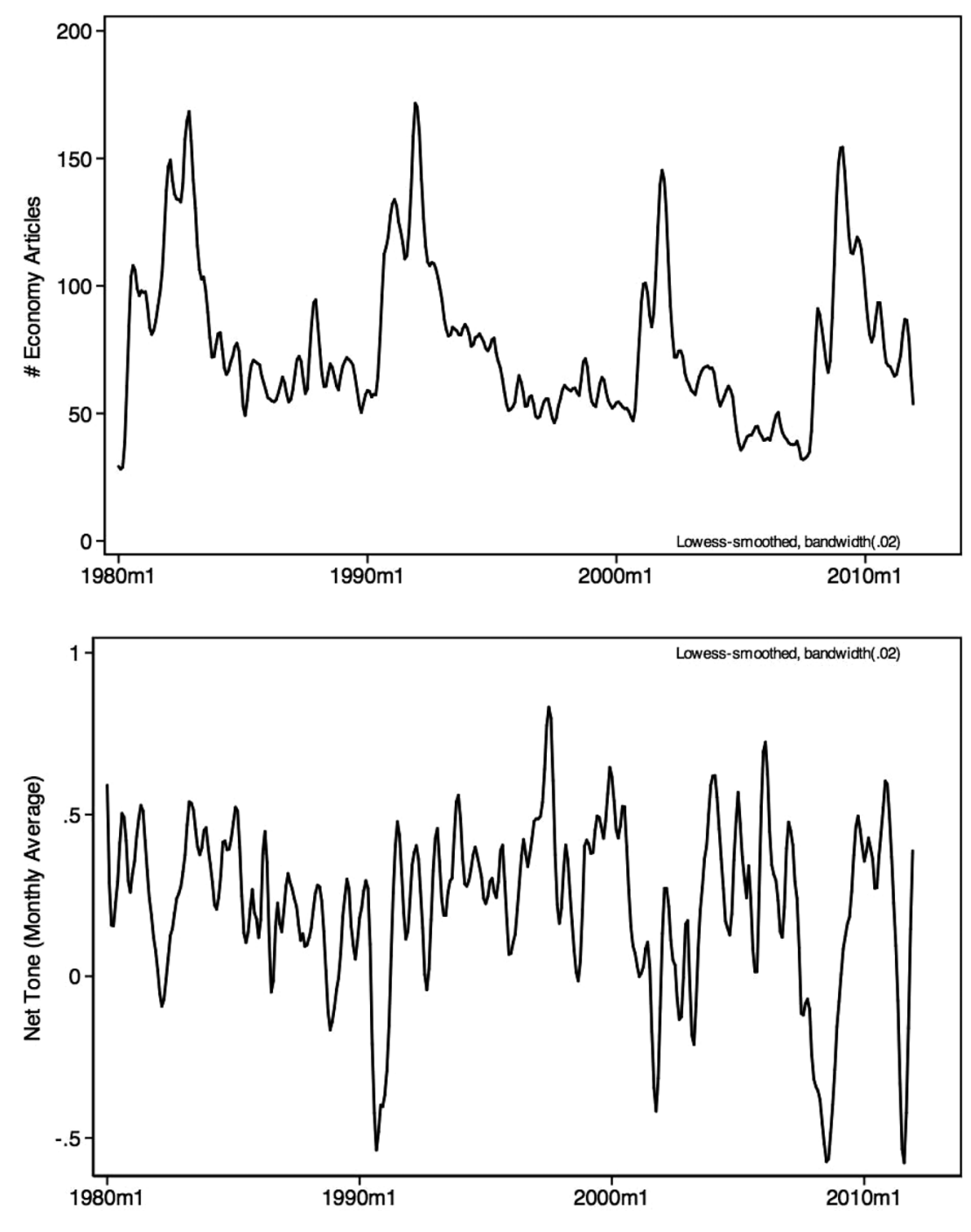

sentiment, one retrospective and the other prospective. ${ }^{13}$ Both are illustrated in Figure 3.

Correlations between all measures are shown in Table 1, in both levels and changes. Even these basic results point to some of the most critical findings below. Note that both the tone and volume of media content are most strongly related to leading, rather than coincident or lagging, economic indicators series. (Tone is related to lagging and coincident indicators as well, but in the

${ }^{13}$ MSCI data are available at http://www.sca.isr.umich.edu. Although they are readily available, we do not focus on egotropic measures here, since these tend to be more reflective of personal experiences, and thus somewhat less connected to national economic indicators. That said, analyses using egocentric measures are also available upon request. Results are not fundamentally different from what is presented here, though all relationships are weaker, as we should expect. wrong direction.) Volume is negatively related to leading indicators $(-0.68)$; tone is positively related $(0.19)$, evidence that coverage increases when the economy is bad (i.e., as tone worsens). Economic sentiment, too, is most powerfully related to leading indicators. This is true for retrospective evaluations, at least; prospective evaluations show no positive correlation with the economy, but they do show a strong positive connection to media tone.

Predictably, relationships between the series in changes, in the bottom panel of Table 1 , are much weaker. Some similar patterns remain, however: retrospective economic sentiment is correlated with leading indicators; prospective sentiment is correlated with media tone; and the volume and tone of economic news are negatively correlated. These are all just preliminary observations, though they do foreshadow forthcoming results. We 
FIGURE 3 Public Opinion about the Economy

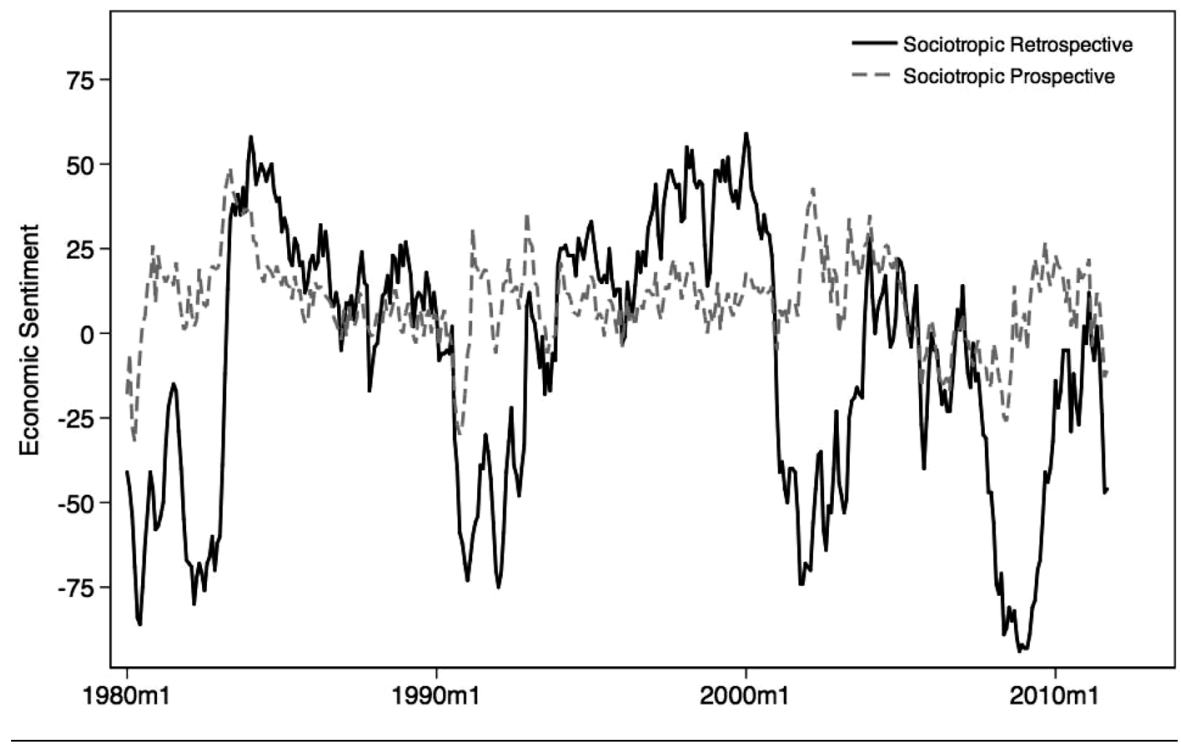

TABLE 1 Bivariate Correlations: Economic, Media, and Public Opinion Measures

\begin{tabular}{|c|c|c|c|c|c|c|}
\hline In (Concurrent) Levels & EI, Lag & EI, Coin & EI, Lead & Volume & Tone & SR \\
\hline EI, Coincident & $0.514^{*}$ & & & & & \\
\hline EI, Leading & -0.072 & $0.664^{*}$ & & & & \\
\hline Volume & -0.019 & $-0.420^{*}$ & $-0.686^{*}$ & & & \\
\hline Tone (LSD) & $-0.355^{*}$ & $-0.167^{*}$ & $0.188^{*}$ & $-0.220^{*}$ & & \\
\hline Sociotropic Retrospective (SR) & $-0.256^{*}$ & $0.191^{*}$ & $0.621^{*}$ & $-0.582^{*}$ & $0.425^{*}$ & \\
\hline Sociotropic Prospective & $-0.507^{*}$ & $-0.506^{*}$ & $-0.266^{*}$ & $0.166^{*}$ & $0.377^{*}$ & $0.265^{*}$ \\
\hline In (Concurrent) Changes & EI, Lag & EI, Coin & EI, Lead & Volume & Tone & SR \\
\hline EI, Coincident & -0.078 & & & & & \\
\hline EI, Leading & $-0.311^{*}$ & $0.544^{*}$ & & & & \\
\hline Volume & 0.056 & -0.078 & $-0.181^{*}$ & & & \\
\hline Tone (LSD) & -0.030 & 0.030 & 0.085 & $-0.135^{*}$ & & \\
\hline Sociotropic Retrospective (SR) & -0.070 & $0.132^{*}$ & $0.339^{*}$ & $-0.142^{*}$ & $0.184^{*}$ & \\
\hline Sociotropic Prospective & -0.068 & $-0.116^{*}$ & 0.047 & -0.047 & $0.176^{*}$ & $0.404^{*}$ \\
\hline
\end{tabular}

Note: $\mathrm{N}$ varies from 338 to 384 , depending on data availability ${ }^{*} \mathrm{p}<.05$.

now turn to a more rigorous examination of the relationships between the economy, media, and public sentiment below.

\section{The Economy and the Media}

We begin with an analysis of the relationship between economic indicators and media coverage. We rely-here and in all subsequent analyses-on time-series error correction models (ECMs), where current changes in a dependent variable are regressed on lagged levels of that variable and both current changes and lagged levels of the independent variable(s) as well. ${ }^{14}$ ECMs have some

\footnotetext{
${ }^{14}$ Note that we use regression models appropriate for interval-level data in spite of the fact that one of our variables, the number of economic news stories, is, strictly speaking, a count variable-it cannot be less than zero, and it takes on only integer values. Neither of these facts is problematic for our analyses, particularly since the number of economic news stories per month is always well above zero. In our data, the minimum value is 17 and the maximum is 239; the variable is positively skewed, then (skewness $=1.16$ ), but it is essentially a normal distribution with a right-hand tail.
} 
TABLE 2 Responsiveness of Media to Lagging, Coincident, and Leading Indicators, Taken Separately

\begin{tabular}{|c|c|c|c|c|c|c|}
\hline \multirow[b]{3}{*}{ EI Type } & \multicolumn{5}{|c|}{ DV } & \\
\hline & \multicolumn{3}{|c|}{$\Delta$ in Count $_{t}$} & \multicolumn{3}{|c|}{$\Delta$ in Tone $_{\mathrm{t}}$} \\
\hline & Lag & Coin & Lead & Lag & Coin & Lead \\
\hline $\mathrm{DV}_{\mathrm{t}-1}$ & $\begin{array}{l}-.201^{* * *} \\
(.032)\end{array}$ & $\begin{array}{l}-.245^{* * *} \\
(.034)\end{array}$ & $\begin{array}{l}-.350^{* * *} \\
(.039)\end{array}$ & $\begin{array}{l}-.555^{* * *} \\
(.046)\end{array}$ & $\begin{array}{l}-.553^{* * *} \\
(.045)\end{array}$ & $\begin{array}{l}-.588^{* * *} \\
(.045)\end{array}$ \\
\hline$\Delta \mathrm{EI}_{\mathrm{t}}$ & $\begin{array}{l}-2.999 \\
(3.269)\end{array}$ & $\begin{array}{c}-14.767^{* * *} \\
(4.065)\end{array}$ & $\begin{array}{c}-6.058^{* * *} \\
(1.539)\end{array}$ & $\begin{array}{l}-.060 \\
(.045)\end{array}$ & $\begin{array}{l}.226^{* * *} \\
(.059)\end{array}$ & $\begin{array}{l}.156^{* * *} \\
(.025)\end{array}$ \\
\hline $\mathrm{EI}_{\mathrm{t}-1}$ & $\begin{array}{l}1.287^{*} \\
(.641)\end{array}$ & $\begin{array}{r}-1.300 \\
(.730)\end{array}$ & $\begin{array}{c}-1.914^{* * *} \\
(.312)\end{array}$ & $\begin{array}{l}-.043^{* * *} \\
(.010)\end{array}$ & $\begin{array}{c}-.030^{* *} \\
(.010)\end{array}$ & $\begin{array}{c}.006 \\
(.004)\end{array}$ \\
\hline Constant & $\begin{array}{l}15.530^{* * *} \\
(2.643)\end{array}$ & $\begin{array}{l}18.908^{* * *} \\
(2.803)\end{array}$ & $\begin{array}{l}26.427^{* * *} \\
(3.067)\end{array}$ & $\begin{array}{l}.121^{* * *} \\
(.018)\end{array}$ & $\begin{array}{l}.120^{* * *} \\
(.017)\end{array}$ & $\begin{array}{l}.129^{* * *} \\
(.017)\end{array}$ \\
\hline $\mathrm{N}$ & 383 & 383 & 383 & 383 & 383 & 383 \\
\hline R-squared & .110 & .130 & .204 & .279 & .290 & .315 \\
\hline
\end{tabular}

Note: Cells contain ordinary least squares (OLS) coefficients with standard errors in parentheses. Count is the total number of articles; tone is net tone based on the LSD.

${ }^{*} \mathrm{p}<.05,{ }^{* *} \mathrm{p}<.01,{ }^{* * *} \mathrm{p}<.001$.

statistical advantages when dealing with nonstationary time series, those that wander in the form of a random walk. ${ }^{15}$ They also have practical advantages as a general modeling approach to representing the relationships between time series, including stationary series. That is, using ECMs, one can determine the specific functional form relating variables (De Boef and Keele 2008). ${ }^{16}$

Most importantly for our purposes, ECMs can provide some insight into the relative impact of short- versus long-term effects of the economy on media content (and, below, the state of public opinion). Consider the general ECM:

$$
\Delta \mathrm{Yt}=\alpha_{0}+\alpha_{1} \mathrm{Y}_{\mathrm{t}-1}+\beta_{0} \Delta \mathrm{X}_{\mathrm{t}}+\beta_{1} \mathrm{X}_{\mathrm{t}-1}+\varepsilon_{\mathrm{t}},
$$

where current changes in $\mathrm{Y}$ are regressed on lagged levels of $\mathrm{Y}$, current changes in $\mathrm{X}$, and lagged levels of $\mathrm{X}$. The error correction rate is captured by $\alpha_{1}$; the short-run effects of $X$ are captured by $\beta_{0}$; and the long-term effects of $X$, referred to as the long-run multiplier (LRM, the total effect that $\mathrm{X}$ has on $\mathrm{Y}$, distributed over time periods $\mathrm{t}+1$ to $\mathrm{t}+\mathrm{k}$ ), are captured by $\beta_{1} /-\alpha_{1}$. In fact, the LRM is more easily observed when the ECM is expressed in its

\footnotetext{
${ }^{15}$ They are particularly advantageous when dealing with nonstationary series that are cointegrated (see, e.g., Durr 1992).

${ }^{16}$ The autoregressive distributed lag (ADL) model is another flexible approach. Here the dependent variable is regressed on lagged levels of that variable and the independent variable(s). Results using the $\mathrm{ADL}$ specification are available upon request.
}

standard form (rather than the equation by which it is estimated, above), as follows:

$$
\Delta \mathrm{Y}_{\mathrm{t}}=\alpha_{0}+\beta_{0} \Delta \mathrm{X}_{\mathrm{t}}+\Phi\left(\mathrm{Y}_{\mathrm{t}-1}-\gamma \mathrm{X}_{\mathrm{t}-1}\right)+\varepsilon_{\mathrm{t}},
$$

where the error correction rate is captured by $\Phi$ and the long-run multiplier is captured by $\gamma \cdot{ }^{17}$ We pay special attention to these separate elements of the ECMs estimated below, as each provides valuable information about the nature of the relationship between media content and the economy. Interpreting each element also requires consideration of the characteristics of the time series, in particular the extent to which changes in the series are transient or long-lasting. This can be assessed using tests for stationarity, which we summarize in Appendix B in the supporting information and discuss when characterizing the results.

Tables 2 and 3 show ECMs in which current changes in media volume and tone are regressed on their own lagged levels, and both current changes and lagged levels of economic indicators. Table 2 shows models for each of

\footnotetext{
${ }^{17}$ The ECM is mathematically equivalent to the standard ADL model including current effects of the independent variable, that is, where levels of $Y$ are regressed on lagged levels of $Y$ and both current and lagged levels of X: $Y_{t}=\alpha_{0}+\alpha_{1} Y_{t-1}+\beta_{0} X_{t}+\beta_{1}$ $X_{t-1}+\varepsilon_{t}$. The coefficient $\beta_{0}$ in this ADL will be identical to the coefficient $\beta_{0}$ in the ECM in Equation (1), and the coefficient $\beta_{1}$ in the ADL will be equal to the difference between $\beta_{0}$ and $\beta_{1}$ in the ECM. (Also, $\alpha_{1}$ in the ADL will be equal to 1 minus $\alpha_{1}$ in the ECM.)
} 
TABLE 3 Responsiveness of Media to Lagging, Coincident, and Leading Indicators, Taken Together

\begin{tabular}{|c|c|c|c|c|c|c|}
\hline \multirow[b]{3}{*}{$\mathrm{DV}_{\mathrm{t}-1}$} & \multicolumn{6}{|c|}{ DV } \\
\hline & \multicolumn{3}{|c|}{$\Delta$ in Count $_{t}$} & \multicolumn{3}{|c|}{$\Delta$ in Tone ${ }_{t}$} \\
\hline & $\begin{array}{c}-.257^{* * *} \\
(.035)\end{array}$ & $\begin{array}{c}-.352^{* * *} \\
(.039)\end{array}$ & $\begin{array}{c}-.379^{* * *} \\
(.041)\end{array}$ & $\begin{array}{c}-.566^{* * *} \\
(.046)\end{array}$ & $\begin{array}{c}-.622^{* * *} \\
(.047)\end{array}$ & $\begin{array}{c}-.620^{* * *} \\
(.047)\end{array}$ \\
\hline \multicolumn{7}{|l|}{ Lagging } \\
\hline$\Delta \mathrm{CI}_{\mathrm{t}}$ & $\begin{array}{c}-2.265 \\
(3.829)\end{array}$ & & $\begin{array}{c}-6.449 \\
(3.793)\end{array}$ & $\begin{array}{c}.006 \\
(.055)\end{array}$ & & $\begin{array}{c}.044 \\
(.056)\end{array}$ \\
\hline $\mathrm{CI}_{\mathrm{t}-1}$ & $\begin{array}{l}1.300 \\
(.967)\end{array}$ & & $\begin{array}{c}-2.242^{*} \\
(1.101)\end{array}$ & $\begin{array}{c}-.017 \\
(.015)\end{array}$ & & $\begin{array}{c}.011 \\
(.016)\end{array}$ \\
\hline \multicolumn{7}{|l|}{ Coincident } \\
\hline$\Delta \mathrm{CI}_{\mathrm{t}}$ & $\begin{array}{r}-11.887^{*} \\
(4.896)\end{array}$ & $\begin{array}{c}2.032 \\
(4.981)\end{array}$ & $\begin{array}{c}-1.127 \\
(5.164)\end{array}$ & $\begin{array}{l}.187^{* *} \\
(.070)\end{array}$ & $\begin{array}{c}.004 \\
(.075)\end{array}$ & $\begin{array}{c}.021 \\
(.077)\end{array}$ \\
\hline $\mathrm{CI}_{\mathrm{t}-1}$ & $\begin{array}{r}-1.870 \\
(.984)\end{array}$ & $\begin{array}{c}.719 \\
(1.019)\end{array}$ & $\begin{array}{c}2.716 \\
(1.415)\end{array}$ & $\begin{array}{c}-.023 \\
(.014)\end{array}$ & $\begin{array}{c}-.043^{* *} \\
(.016)\end{array}$ & $\begin{array}{c}-.052^{*} \\
(.021)\end{array}$ \\
\hline \multicolumn{7}{|l|}{ Leading } \\
\hline$\Delta \mathrm{CI}_{\mathrm{t}}$ & & $\begin{array}{c}-5.790^{* *} \\
(2.142)\end{array}$ & $\begin{array}{c}-7.001^{* *} \\
(2.213)\end{array}$ & & $\begin{array}{l}.116^{* * *} \\
(.032)\end{array}$ & $\begin{array}{l}.124^{* * *} \\
(.034)\end{array}$ \\
\hline $\mathrm{CI}_{\mathrm{t}-1}$ & & $\begin{array}{c}-2.138^{\text {*** }} \\
(.426)\end{array}$ & $\begin{array}{c}-2.568^{* * *} \\
(.505)\end{array}$ & & $\begin{array}{l}.016^{* *} \\
(.006)\end{array}$ & $\begin{array}{c}.017^{*} \\
(.006)\end{array}$ \\
\hline Constant & $\begin{array}{l}19.827^{* * *} \\
(2.876)\end{array}$ & $\begin{array}{l}26.501^{\text {*** }} \\
(3.080)\end{array}$ & $\begin{array}{l}28.509^{* * *} \\
(3.200)\end{array}$ & $\begin{array}{l}.123^{\text {*** }} \\
(.017)\end{array}$ & $\begin{array}{l}.139^{* * *} \\
(.018)\end{array}$ & $\begin{array}{l}.139^{* * *} \\
(.018)\end{array}$ \\
\hline $\mathrm{N}$ & 383 & 383 & 383 & 383 & 383 & 383 \\
\hline R-squared & .138 & .205 & .215 & .294 & .329 & .330 \\
\hline
\end{tabular}

Note: Cells contain OLS coefficients with standard errors in parentheses. Count is the total number of articles; tone is net tone based on the LSD.

${ }^{*} \mathrm{p}<.05,{ }^{* *} \mathrm{p}<.01,{ }^{* * *} \mathrm{p}<.001$.

our two measures of media content: volume and tone. ${ }^{18}$ In each case, we examine, separately, the impact of lagging, coincident, and leading indicators. Table 3 includes models that combine all three economic indicators series, entered simultaneously in models of media content.

We begin our discussion with a simple diagnostic issue: Does media coverage reflect past, current, or future economic trends? Results in these tables are relatively clear on this issue-media volume and tone are most strongly related to indicators of both the present and the future. Results in Table 2 suggest that changes in media coverage are not at all related to changes in the levels of lagging indicators. This is perhaps as we should expect; media most likely do not report what happened months ago. Results are different using current and future economic

\footnotetext{
${ }^{18}$ Although we address the possibility of a measure that combines volume and tone, both in the supporting information and in models of public opinion below, we do not use a Volume $\times$ Tone measure as a dependent variable here. Doing so produces a model that is not very different from the model of tone, however; results are available upon request.
}

indicators, as the results in Table 2 reveal that media coverage is systematically related to both; R-squared values actually suggest that the future matters somewhat more than the present.

The relative importance of the future economy is clearer in Table 3. Here we examine the relative impact of indicators series by including them simultaneously in the same models. The first model compares lagging and coincident indicators; the second includes coincident and leading indicators; the third compares all three. As we would expect given Table 2 results, coincident indicators dominate lagging ones, but leading indicators dominate coincident ones. Indeed, in the saturated model, only leading indicators are statistically significant in both changes and levels.

Clearly, media content is responsive mainly to leading indicators. This is not an insignificant finding. A good deal of work in political communication, and in economics as well, focuses on media content as a function of current economic conditions. It most certainly is, at least in part. But media content on the economy appears to be 
TABLE 4 The Short- and Long-Term Impacts of the Economy on Media Content

\begin{tabular}{lcc}
\hline & Count & Tone \\
\hline Rate of Error Correction $(\Phi)$ & -.350 & -.588 \\
Short-Term Effect $\left(\beta_{0}\right)$ & -6.058 & .156 \\
Long-Run Multiplier $(\gamma)$ & -5.469 & ns \\
\hline
\end{tabular}

Note: Based on models using leading indicators in Table 2.

substantially future-oriented. That is, it responds more to where the economy is going, not where it has been or currently is. This has potentially important consequences for public opinion and politics (discussed further below).

What about the relative impact of short-term change in, versus long-term levels of, economic indicators? Table 4 summarizes the results from what appear to be our "best" models-models that rely on leading indicators alone (from Table 2).

Table 4 shows values for the error correction rate, the short-term impact of changes in the economy, and the long-run multiplier effect of economic levels. Each provides useful information about the relationship between the economy and media content; see our discussion of Equations (1) and (2) above. Consider first the model for the number of articles dealing with the economy. From the third column of Table 2, a one-unit upward change in leading indicators leads to a roughly 6.1-article decrease in the current month. (In practice, changes are typically smaller; the interquartile range for monthly changes in the leading indicators series is -0.23 to +0.3 .) This is the immediate impact of a one-unit increase. There also is a long-term impact that alters the equilibrium level of coverage. We know this for two reasons: (1) The coefficient for the lagged level of leading economic indicators in Table 2 is statistically significant, and (2) leading economic indicators is a nonstationary variable, meaning that changes to it are permanent and persist into the future (see Appendix B in the supporting information). The latter is important because an increase or a decrease cannot have a long-term effect if it does not last.

The long-term impact is not directly estimated in Table 2 and must be calculated from the coefficient $(-1.91)$ for the lagged level of leading indicators as well as the error correction parameter $(-0.35)$. Simple division shows the impact to be 5.5 articles. The short-run impact thus exceeds the long-run impact by a small amount, and we know from the error correction parameter that the difference is corrected at a rate of 0.35 on average, that is, about a third of the remaining disequilibrium each month. The impact of the economy thus is immediate and fairly long-lasting, as nearly three-quarters of the immediate effect (5.5 of 6.1) persists, influencing coverage into the future.

Things are quite different for media tone. Here the short-term impact of a one-unit change in leading indicators is 0.16 . (As the interquartile range for tone is 0.03 to 0.43 , this is no small shift.) There is no real long-term impact, however. The coefficient for lagged leading indicators is 0.006 and not statistically significant. This comes as little surprise, as time-series diagnostics in Appendix B in the supporting information reveal that changes to tone are short-lived-indeed, less than $50 \%$ of a change in tone remains after a month, less than $25 \%$ the following month. Clearly, where tone is concerned, the impact of the economy occurs through short-term changes; although sizable, the effects do not stand the test of time. ${ }^{19}$ This is of consequence for our analysis of public opinion, as we will see.

\section{The Economy, the Media, and Public Sentiment}

How does media content influence public economic sentiment? Answering the question is not straightforward, as there is reason to suppose that public economic sentiment influences media coverage itself. This may be true for various reasons. Journalists may be representative of the broader population. They also may see themselves as representatives, aiming to reflect public concerns because it is the right thing to do. Of course, in a competitive marketplace, they also have incentives to produce content reflecting what consumers want.

Only a handful of studies have considered the possibility of bidirectional causality between media and opinion. Some find evidence of causality running in both directions. Indeed, Stevenson, Gonzenbach, and David

\footnotetext{
${ }^{19}$ Separate analyses using the unemployment rate reveal a similar pattern: short-term changes in economic conditions (particularly for unemployment) matter, whereas long-term levels do not. See Appendix $\mathrm{C}$ in the supporting information for further discussion; results are available upon request.
} 


\section{TABLE 5 Tests of Causality}

\begin{tabular}{|c|c|c|c|}
\hline & \multicolumn{3}{|c|}{ DV } \\
\hline & $\begin{array}{c}\text { Economic } \\
\text { Evaluations }\end{array}$ & $\begin{array}{l}\text { Media: } \\
\text { Count }\end{array}$ & $\begin{array}{c}\text { Media: } \\
\text { Tone }\end{array}$ \\
\hline \multicolumn{4}{|l|}{ Retrospective Evaluations } \\
\hline Economic Evaluations & - & $5.854^{*}$ & $15.590^{* * *}$ \\
\hline Leading Indicators & .759 & $18.565^{* * *}$ & .416 \\
\hline Media: Count & .069 & - & 2.687 \\
\hline Media: Tone & $19.228^{* * *}$ & 1.267 & - \\
\hline \multicolumn{4}{|l|}{ Prospective Evaluations } \\
\hline Economic Evaluations & - & 1.891 & $18.840^{* * *}$ \\
\hline Leading Indicators & $5.433^{*}$ & $33.693^{* * *}$ & $4.152^{*}$ \\
\hline Media: Count & 1.874 & - & .281 \\
\hline Media: Tone & $2.938^{\mathrm{a}}$ & 1.818 & - \\
\hline
\end{tabular}

Note: Cells contain chi-square values from tests of statistical significance, based on VAR models using a single lag of all variables in levels.

${ }^{\mathrm{a}} \mathrm{p}<.10,{ }^{*} \mathrm{p}<.05,{ }^{* *} \mathrm{p}<.01,{ }^{* * *} \mathrm{p}<.001$.

(1994) find that public perceptions of the economy have a stronger effect on media coverage than coverage has on perceptions; Haller and Norpoth (1997) reach a similar conclusion; and Wu et al. (2002) find a more balanced, but clearly bidirectional, relationship. Another body of work points toward a simple unidirectional effect of media on opinion: Each of Fan (1993), Blood and Phillips (1995, 1997), and Hollanders and Vliegenthart (2011) find that media coverage Granger-causes economic perceptions, and not the other way around.

Is there evidence of bidirectional causality in our media and opinion data? To begin with, Table 5 shows tests of Granger causality for four variables: sociotropic economic evaluations, and both media count and tone. ${ }^{20}$ The table contains estimates from vector autoregression (VAR) models, using a single lag of each variable, with all variables measured in levels. The top panel shows results for retrospective evaluations and the bottom panel results for prospective evaluations.

Recall that we are mostly interested in the relationships between these evaluations and media coverage. The

${ }^{20}$ We do not include a model using leading economic indicators (LEIs) as the dependent variable. Those results suggest that tone and both retrospective and prospective evaluations cause leading economic indicators, implying that the public and mass media effectively anticipate leading economic indicators, or that the latter actually reflect the former. This is true even when our revised LEI measure excludes consumer expectations. The possibility that leading indicators are not exogenous to our other measures is, of course, rather problematic. That said, we do not fully trust these results; because the leading indicator series is nonstationary, vector autoregression results are problematic.

\section{TABLE 6 Responsiveness of Media Coverage to Economic Evaluations (and the Economy)}

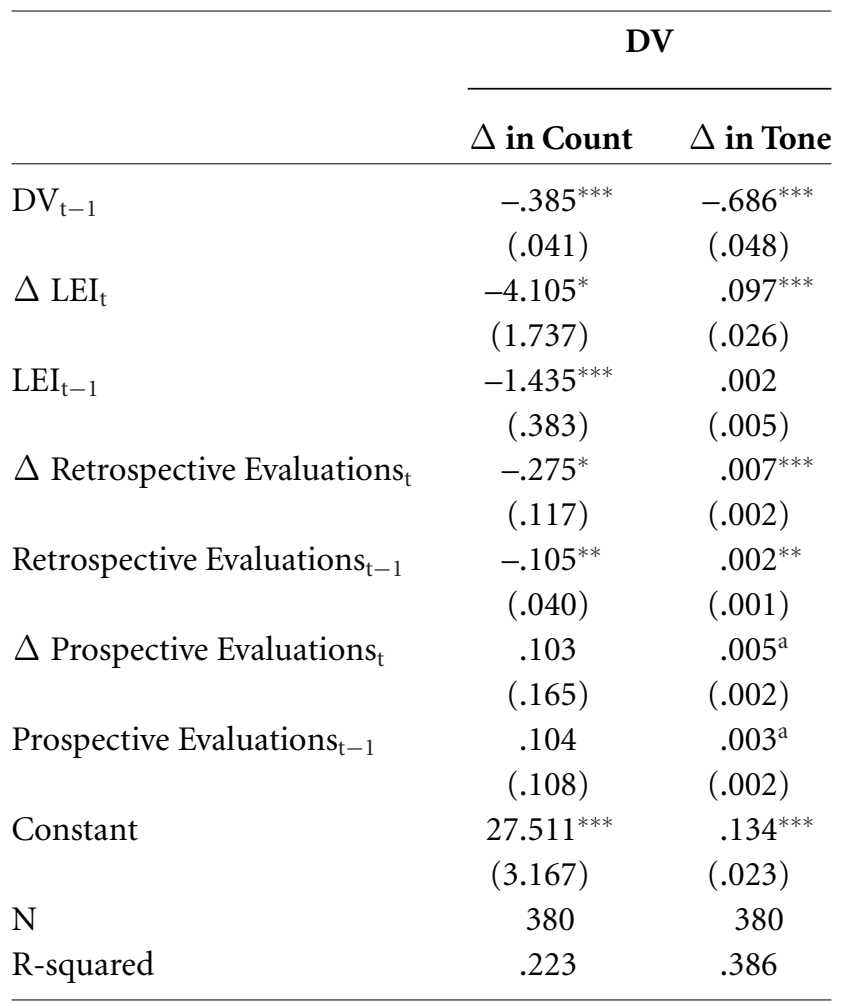

Note: Cells contain OLS coefficients with standard errors in parentheses.

${ }^{\mathrm{a}} \mathrm{p}<.10,{ }^{*} \mathrm{p}<.05,{ }^{* *} \mathrm{p}<.01,{ }^{* * *} \mathrm{p}<.001$.

results do suggest the possibility of bidirectional causality, at least with respect to media tone. In each case, the content of media coverage leads public opinion, but opinion leads coverage as well. This is especially true for retrospective evaluations; for prospective assessments, the analysis implies that causality runs primarily from the public to media coverage, as the impact of media on evaluation is not highly reliable $(\mathrm{p}<.10)$. Of course, Granger tests offer limited information, particularly where we expect that relationships are current, not lagged. While these tests provide some useful diagnostics, then, they cannot really resolve the issue of directionality in such circumstances.

That said, we can estimate ECMs of both opinion and media coverage that include the other potentially endogenous variable. For instance, current changes in opinion can be modeled as a function of lagged opinion, current changes and lagged levels of media content, and current changes and lagged levels of leading indicators. The coefficient for current changes in media content can tell us little about the effect of media on public opinion, as it may be that it also captures the reciprocal effect of opinion on coverage. But the effect of lagged levels of media 
TABLE 7 Responsiveness of Economic Evaluations to Media (and the Economy)

\begin{tabular}{|c|c|c|c|c|}
\hline \multirow[b]{3}{*}{$\mathrm{DV}_{\mathrm{t}-1}$} & \multicolumn{4}{|c|}{ DV } \\
\hline & \multicolumn{2}{|c|}{$\Delta$ in Retrospective Evaluations } & \multicolumn{2}{|c|}{$\Delta$ in Prospective Evaluations } \\
\hline & $-.082^{* * *}$ & $-.081^{* * *}$ & $-.241^{* * *}$ & $-.241^{\text {*** }}$ \\
\hline & $(.017)$ & $(.017)$ & $(.031)$ & $(.031)$ \\
\hline \multirow[t]{2}{*}{$\Delta \mathrm{LEI}_{\mathrm{t}}$} & $3.836^{* * *}$ & $3.697^{* * *}$ & $1.214^{*}$ & $1.216^{\mathrm{a}}$ \\
\hline & $(.843)$ & $(.846)$ & $(.617)$ & $(.619)$ \\
\hline \multirow[t]{2}{*}{$\mathrm{LEI}_{\mathrm{t}-1}$} & -.089 & -.080 & $-.316^{* *}$ & $-.316^{* *}$ \\
\hline & $(.169)$ & $(.169)$ & $(.118)$ & $(.118)$ \\
\hline \multirow[t]{2}{*}{$\Delta$ Media Count $_{t}$} & -.042 & -.042 & -.001 & -.001 \\
\hline & $(.025)$ & $(.025)$ & $(.018)$ & $(.018)$ \\
\hline \multirow[t]{2}{*}{ Media Count ${ }_{t-1}$} & -.037 & $-.045^{*}$ & .016 & .016 \\
\hline & $(.022)$ & $(.022)$ & $(.015)$ & $(.015)$ \\
\hline \multirow[t]{2}{*}{$\Delta$ Media Tone $_{\mathrm{t}}$} & $8.977^{* * *}$ & $8.672^{* * *}$ & $4.882^{* * *}$ & $4.887^{* * *}$ \\
\hline & $(1.670)$ & $(1.677)$ & $(1.200)$ & $(1.206)$ \\
\hline \multirow[t]{2}{*}{ Media Tone t-1 $_{1}$} & $9.670^{* * *}$ & 4.464 & $4.200^{* *}$ & 4.304 \\
\hline & $(1.890)$ & $(3.716)$ & $(1.377)$ & $(2.630)$ \\
\hline \multirow[t]{2}{*}{ Interaction: Count $\times$ Tone $_{\mathrm{t}-1}$} & & .068 & & -.001 \\
\hline & & $(.042)$ & & $(.031)$ \\
\hline \multirow[t]{2}{*}{ Constant } & .095 & .844 & .034 & .017 \\
\hline & $(1.735)$ & $(1.791)$ & $(1.249)$ & $(1.303)$ \\
\hline $\mathrm{N}$ & 380 & 380 & 380 & 380 \\
\hline R-squared & .231 & .236 & .180 & .180 \\
\hline
\end{tabular}

Note: Cells contain coefficients with standard errors in parentheses from OLS models.

${ }^{\mathrm{a}} \mathrm{p}<.10,{ }^{*} \mathrm{p}<.05^{* *} \mathrm{p}<.01,{ }^{* * *} \mathrm{p}<.001$.

content is likely more revealing about the effect of media on opinion. There is little basis for supposing that previous coverage would be endogenous to current changes in opinion, after all; lagged levels of media content are likely exogenous. The same is true for a model of media coverage that includes lagged opinion as a regressor. Using these ECMs, then, we may be able to identify "true" lagged effects of media coverage on opinion, as well as lagged effects of opinion on media coverage. ${ }^{21}$

Table 6 shows results for ECMs of media content. Here changes in either the count or tone of media content are regressed on (a) lagged levels of media content, (b) current changes and lagged levels of both retrospective and prospective economic sentiment, and (c) current changes and lagged levels of leading indicators. As we have already seen, media content reflects the state of the economy, primarily in current changes. Results in Table 6 also suggest that economic evaluations may find their

\footnotetext{
${ }^{21}$ To be clear: note that although we estimate the effects of current changes in both equations, endogeneity means that we cannot conclude anything about the true nature of this concurrent relationship. But lagged levels, which are likely exogenous, can be revealing.
}

way into media content. Again, we only take seriously the lagged effects of public opinion, which presumably are exogenous to current changes in tone. That the coefficients for the lagged variables are meaningfully (and significantly) smaller than those for changes may indicate that changes in public opinion actually are endogenous to changes in media coverage. (In other words, endogeneity may be inflating the coefficients relating the two concurrently.) Regardless, these models make clear that lagged opinion may influence media content independent of the economy. And, importantly, it is retrospective evaluations that matter most. ${ }^{22}$ This is a useful reminder that media content is not entirely driven by prospective features of the economy-recall results in Tables 2 and 3 showing media responsiveness to coincident indicators as well. (That said, even retrospective evaluations respond in part to prospective economic trends, as we shall see below.)

Table 7 examines the opposite relationship: the effect of media on economic sentiment, both retrospective

\footnotetext{
${ }^{22}$ Note that running the same models without the LEI does not fundamentally change the relative importance of retrospective over prospective evaluations.
} 
FIGURE 4 Leading Indicators and Media Tone during the Great Recession
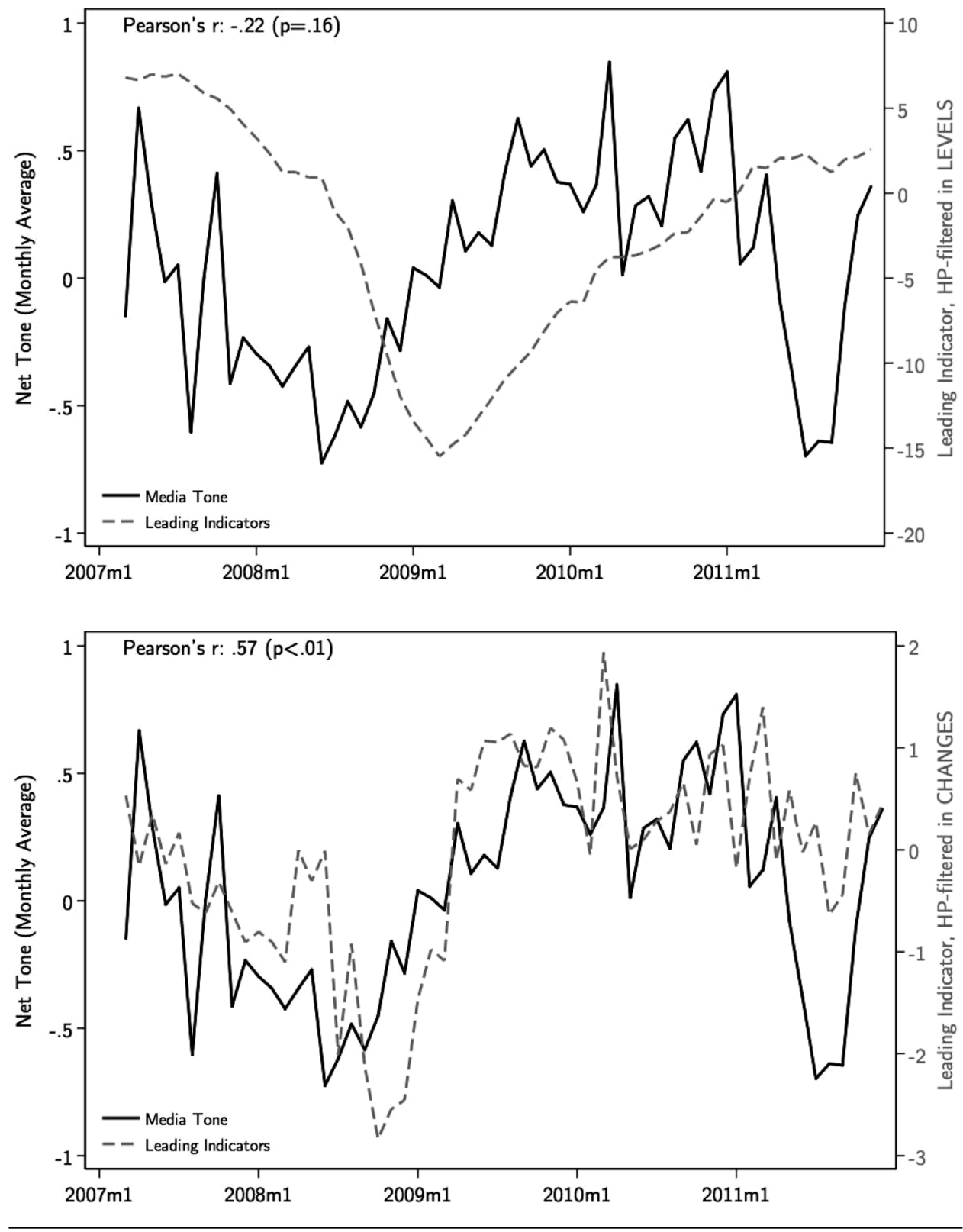

and prospective. Changes in sentiment are regressed on (a) lagged levels of sentiment, (b) current changes and lagged levels of media content, and (c) current changes and lagged levels of leading indicators. A model also shows the results of including an interaction between media count and tone, allowing for the possibility that the impact of tone increases alongside the volume of coverage.

Results suggest that economic sentiment is related to both the actual economy and media coverage. Changes in leading economic indicators have a positive current effect on both retrospective and prospective assessments. Interestingly, the effect of changes in these future-oriented indicators is largest and most reliable for retrospections. Prospections are driven more by the level of leading indicators, which actually have a negative effect on prospections; that is, as the future economy gets better, expectations about the future get worse. This makes sense given that leading economic indicators point to comparatively short-run economic developments and that changes in those indicators are most predictive of economic change (Wlezien and Erikson 1996). The effect largely comports with what Katona (1972) found, specifically, that economic expectations are most optimistic when the level of the economy is at its worst. 
Media coverage also matters for economic evaluations, almost entirely through tone. (Coefficients for both tone and count change little when each is included independently, so we include just the complete model here.) The number of articles is not a statistically significant determinant, but the tone quite clearly is. Interacting count and tone, in the second models in Table 7, also adds nothing beyond what we get from tone on its own, though the coefficient in the model of retrospective evaluations does point in the expected direction (i.e., an increase in the impact of tone when volume increases).

As in Table 6, the effects of current changes in Table 7 tell us nothing about the impact of media coverage on opinion, but the effects of lagged levels do. That the coefficients for changes and levels in media tone are about the same in each equation is suggestive about current effects, but we stop short of drawing this conclusion. All we can surmise is that lagged levels of tone influence public evaluations of the economy above and beyond the effects of leading economic indicators. That said, the effect of tone is only temporary. This is because tone is a stationary variable, and so changes to it are themselves not permanent (see Appendix B in the supporting information and the discussion surrounding Table 4). By definition, then, the impact of tone on evaluations is significant, but it does not last. ${ }^{23}$

\section{Discussion and Conclusions}

Preceding sections have explored the nature of the relationship between the economy, news coverage, and public sentiment. The analyses point to some interesting and important results. First, media content is more likely to reflect leading indicators than either coincident or lagging ones. Second, it is current changes in those prospective conditions that matter most. So media content reflects the change in the future economy more than it reflects the level of economic conditions.

The Great Recession is illustrative. The top panel of Figure 4 shows two lines: One is levels of the leading indicators series, and the other is media tone. Each is shown from 2007-2011 inclusive to the present, to highlight the period of the Great Recession. Most striking is the marked improvement in media tone beginning in mid-2008, even as the economy continued to decline.

This begs the question: Why does media content improve even as the economy continues to falter? The answer

\footnotetext{
${ }^{23}$ The negative effect of leading indicators on prospections, by contrast, is long term. This is partially moderated by the effect of media tone, which itself reflects leading indicators, as we saw in Tables 3 and 6 .
}

lies in the media focus on changes over levels. Consider the link between media content and the economy illustrated in the bottom panel of Figure 4. This figure is based on exactly the same data. Here, however, leading indicators are shown not in levels, but in changes. The Pearson's correlation is 0.59 ; the two series are strongly related. Media tone may not match well with levels of the economy, then, but it is powerfully connected to changes in those conditions. ${ }^{24}$ In the case of the recession, this meant an improvement in media tone even as the economy continued to decline, that is, because the rate of economic decline slowed.

This is not a finding peculiar to the recession, of course-as previous analyses have demonstrated, these results hold even when we use a much longer time period (and also when we exclude the Great Recession). Media content regularly reacts more to changes than to levels of mainly prospective economic conditions. The finding is of real consequence for those interested in how the public reacts to economic information. Past work shows that media content on economic issues matters, above and beyond the economy itself. Our analysis of both retrospective and prospective economic sentiment provides further evidence of this relationship. But if media matter, and if media capture-mostly, at least-the tone of changes in the future economy, then we should expect to see public opinion react not so much to what currently is going on in the economy, but what is likely to be going on soon. This has implications for consumer behavior; it also has implications for economic voting and a wide range of policy attitudes. It also may make more understandable the tendency to reward politicians based on the magnitude and direction of economic change, and especially where the economy is going (e.g., Erikson, MacKuen, and Stimson 2002).

The fact that media variables are statistically significant predictors of public perceptions need not mean that media coverage actually causes those perceptions. It may be that media measures just do a very good job of capturing the economy itself, better even than particular economic indicators. While we cannot readily distinguish this possibility from direct media causality, we can (and

\footnotetext{
${ }^{24}$ Note that the figures show the relationship between levels of media tone and economic indicators (in levels and changes), although the ECMs focus on changes in media tone. A simple algebraic manipulation-adding the lagged dependent variable to both sides of the equation-produces a model in which the level of media tone is a function of lagged tone and the change in the economy. Representing our results in terms of levels of media tone is thus unproblematic; the implication is that the magnitude of coefficients in the ECM speaks not just to the relative weight of short-term change and long-term levels in changes in the dependent variable, but in levels of that variable as well.
} 
do) assess the "mediation" of economic conditions and the relationship(s) between media content and public perceptions. This has been our objective here, though future work might consider carefully the degree to which media move us closer to, or further away from, an accurate assessment of the economy.

Future work might also examine the degree to which these findings are generalizable to other countries, other news topics, and a wider variety of news sources. Our suspicion is that the findings are broadly generalizable, but that there is some variation as well. Whether and the extent to which that is true remains to be seen.

\section{References}

Aalberg, Toril, Jesper Strömbäck, and Claes H. de Vreese. 2012. "The Framing of Politics as Strategy and Game: A Review of Concepts, Operationalizations and Key Findings." Journalism 13(2): 162-78.

Abramowitz, Alan I. 1988. "An Improved Model for Predicting Presidential Election Outcomes." PS: Political Science and Politics 21(4): 843-47.

Altheide, David L. 1997. "The News Media, the Problem Frame, and the Production of Fear." The Sociological Quarterly 38(4): 647-68.

Alvarez, Michael, and Jonathan Nagler. 1995. "Economics, Issues and the Perot Candidacy: Voter Choice in the 1992 Presidential Election." American Journal of Political Science 39(3): 714-44.

Anderson, Christopher J., and Christopher Wlezien. 1997. "The Economics of Politics in Comparative Perspective Revised." Political Behavior 19(1): 1-6.

Bartels, Larry, and John Zaller. 2001. "Presidential Vote Models: A Recount." PS: Political Science and Politics 34: 9-20.

Bennett, W. Lance. 1997. "Cracking the News Code: Some Rules That Journalists Live By." In Do the Media Govern? Politicians, Voters, and Reporters in America, ed. Shanto Iyengar and Richard Reeves. Thousand Oaks, CA: Sage, 103-17.

Blood, Deborah J., and Peter C. B. Phillips. 1995. "Recession Headline News, Consumer Sentiment, the State of the Economy and Presidential Popularity: A Time Series Analysis 1989-1993." International Journal of Public Opinion Research 7(1): 2-22.

Blood, Deborah J., and Peter C. B. Phillips. 1997. "Economic Headline News on the Agenda: New Approaches to Understanding Causes and Effects." In Communication and Democracy: Exploring the Intellectual Frontiers in AgendaSetting Theory, ed. Maxwell McCombs, Donald L. Shaw, and David Weaver. Mahwah, NJ: Lawrence Erlbaum, 97113.

Boomgaarden, Hajo G., Joost van Spanje, Rens Vliegenthart, and Claes H. de Vreese. 2011. "Covering the Crisis: Media Coverage of the Economic Crisis and Citizens' Economic Expectations." Acta Politica 46(4): 353-79.
Boykoff, Maxwell T., and Jules M. Boykoff. 2007. "Climate Change and Journalistic Norms: A Case Study of U.S. Mass Media Coverage." Geoforum 38(6): 1190-1204.

Campbell, James. 1996. "Polls and Votes: The Trial-Heat Presidential Election Forecasting Model, Certainty, and Political Campaigns." American Politics Research 24(4): 408-33.

Carroll, Christopher D. 2003. "Macroeconomic Expectations of Households and Professional Forecasters." Quarterly Journal of Economics 118(1): 269-98.

Chappell, Henry, and William R. Keech. 1985. "A New View of Political Accountability of Economic Performance.” American Political Science Review 79(1): 10-27.

Clarke, Harold D., and Marianne C. Stewart. 1995. "Economic Evaluations, Prime Ministerial Approval and Governing Party Support: Rival Models Reconsidered.” British Journal of Political Science 25(2): 145-70.

Conference Board. 2001. Business Cycle Indicators Handbook. New York: Conference Board.

Davis, Richard. 1992. The Press and American Politics. New York: Longman.

De Boef, Suzanna, and Luke Keele. 2008. "Taking Time Seriously.” American Journal of Political Science 52(1): 184-200.

De Boef, Suzanna, and Paul Kellstedt. 2004. "The Political (and Economic) Origins of Consumer Confidence." American Journal of Political Science 48(4): 933-49.

Doepke, Jorg, Jonas Dovern, Ulrich Fritsche, and Jirka Slacalek. 2008. "The Dynamics of European Inflation Expectations." B. E. Journal of Macroeconomics, 8(1): 1-23.

Doms, Mark, and Norman Morin. 2004. "Consumer Sentiment, the Economy, and the News Media." Federal Reserve Board of San Francisco Working Paper 2004-09.

Durr, Robert H. 1992. "An Essay on Cointegration and Error Correction Models." Political Analysis 4: 185-228.

Durr, Robert H. 1993. "What Moves Policy Sentiment?” American Political Science Review 87(1): 158-70.

Erikson, Robert S. 1989. "Economic Conditions and the Presidential Vote.” American Political Science Review 83(2): 56773.

Erikson, Robert S., Michael B. MacKuen, and James A. Stimson. 2002. The Macro Polity. Cambridge: Cambridge University Press.

Erikson, Robert S., and Christopher Wlezien. 2012. The Timeline of Presidential Elections. Chicago: University of Chicago Press.

Fan, David. 1993. "Predictions of Consumer Confidence/Sentiment from the Press." Presented at the annual meeting of the American Association of Public Opinion Research.

Farnsworth, Stephen J., and S. Robert Lichter. 2006. The Mediated Presidency: Television News and Presidential Governance. Lanham, MD: Rowman and Littlefield.

Farnsworth, Stephen J., and S. Robert Lichter. 2011. "The Return of the Honeymoon: Television News Coverage of New Presidents, 1981-2009.” Presidential Studies Quarterly 41(3): 590-603.

Fiorina, Morris. 1981. Retrospective Voting in American National Elections. New Haven, CT: Yale University Press. 
Fogarty, Brian J. 2005. "Determining Economic News Coverage." International Journal of Public Opinion Research 17(2): 149-72.

Fuller, Jack. 2010. What Is Happening to News? The Information Explosion and the Crisis in Journalism. Chicago: University of Chicago Press.

Glynn, Carroll J., Michael E. Huge, and Lindsay H. Hoffman. 2008. "Did the Media Help Inflate the Housing Bubble? Media Coverage of Real Estate Markets in Times of Change." Presented at the Association for Education in Journalism \& Mass Communication Annual Conference.

Goidel, Kirby, Stephen Procopio, Dek Terrell, and H. Dennis Wu. 2010. "Sources of Economic News and Economic Expectations." American Politics Research 38(4): 759-77.

Happy, J. R. 1986. "Voter Sensitivity to Economic Conditions: A Canadian-American Comparison." Comparative Politics 19(1): 45-56.

Harrington, David E. 1989. "Economic News on Television: The Determinants of Coverage.' Public Opinion Quarterly 53(1): 566-74.

Haller, H. Brandon, and Helmut Norpoth. 1997 "Reality Bites: News Exposure and Economic Opinion.” Public Opinion Quarterly 61: 555-75.

Hetherington, Marc J. 1996. “The Media's Role in Forming Voters' National Economic Evaluations in 1992." American Journal of Political Science 40(2): 372-95.

Hibbs, Douglas A., Jr. 1987. The American Political Economy. Cambridge, MA: Harvard University Press.

Hodrick, Robert, and Edward C. Prescott. 1997. "Postwar U.S. Business Cycles: An Empirical Investigation." Journal of Money, Credit, and Banking 29(1): 1-16.

Holbrook, Thomas. 1994. "Campaigns, National Conditions, and U.S. Presidential Elections." American Journal of Political Science 38(4): 973-98.

Hollanders, David, and Rens Vliegenthart. 2011. “The Influence of Negative Newspaper Coverage on Consumer Confidence: The Dutch Case." Journal of Economic Psychology 32(3):36773.

Jamieson, Kathleen Hall. 1992. Dirty Politics. New York: Oxford University Press.

Katona, George. 1972. “Theory of Expectations.” In Human Behavior and Economic Affairs, ed. Burkhard Strumpel, James N. Morgan, and Ernest Zahn. San Francisco, CA: Jossey-Bass, 549-82.

Kayser, Mark A., and Christopher Wlezien. 2011. "Performance Pressure: Patterns of Partisanship and the Economic Vote." European Journal of Political Research 50(3): 365-94.

Klein, Ezra. 2010. "Do News Media Spend Too Much Time on News?” Washington Post, June 22. http://goo.gl/g1tWBK.

Kuklinski, James H., and Darrell M. West. 1981. "Economic Expectations and Voting Behavior in United States House and Senate Elections." American Political Science Review 75(2): 436-47.

Lamla, Michael J., and Sarah M. Lein. 2008. "The Role of Media for Consumers' Inflation Expectation Formation.” KOF Swiss Economic Institute Working Paper 201.

Levanon, Gad, Ataman Ozyildirim, Brian Schaitkin, and Justyna Zabinska. 2011. "Comprehensive Benchmark Revisions for the Conference Board Leading Economic Index for the United States." Conference Board Working Paper EPWP1106.

Lewis-Beck, Michael S. 1988a. Economics and Elections: The Major Western Democracies. Ann Arbor, MI: University of Michigan Press.

Lewis-Beck, Michael S. 1988b. "Economics and the American Voter: Past, Present, Future.” Political Behavior 19(1): 5-21.

Lewis-Beck, Michael S., and Mary Stegmaier. 2000. "Economic Determinants of Electoral Outcomes." Annual Review of Political Science 3: 183-219.

Lewis-Beck, Michael S., and Mary Stegmaier. 2007. "Economic Models of Voting." In The Oxford Handbook of Political Behavior, ed. Russell Dalton and Hans-Dieter Klingemann. Oxford: Oxford University Press, 518-37.

Linn, Suzanna, Jonathan Nagler, and Marco A. Morales. 2010. "Economics, Elections, and Voting Behavior." In The Oxford Handbook of American Elections and Political Behavior, ed. Jan E. Leighley. Oxford: Oxford University Press, 375-96.

Lipset, Seymour M. 1993. "The Significance of the 1992 Election." PS: Political Science and Politics 26(1): 7-16.

Lockerbie, Brad. 1991. "Prospective Economic Voting in U.S. House Elections.” Legislative Studies Quarterly 16(2): 23961.

MacKuen, Michael B., Robert S. Erikson, and James A. Stimson. 1992. "Peasants or Bankers? The American Electorate and the U.S. Economy." American Political Science Review 86(3): 597-611.

Matthews, J. Scott, Mark Pickup, and Fred Cutler. 2012. "The Mediated Horserace: Campaign Polls and Poll Reporting." Canadian Journal of Political Science 45(2): 261-87.

Mazur, Allan. 2009. “American Generation of Environmental Warnings: Avian Influenza and Global Warming." Human Ecology Review 16(1): 17-26.

Mazur, Allan, and Linling Lee. 1993. "Sound the Global Alarm: Environmental Issues in the US National News." Social Studies of Science 23: 681-720.

Mazur, Allan, and Linling Lee. 2003. "Sounding the Global Alarm: Environmental Issues in the U.S. National News." Social Studies of Science 23(4): 681-720.

McComas, Katherine, and James Shanahan. 1999. “Telling Stories about Global Climate Change: Measuring the Impact of Narratives on Issue Cycles." Communication Research 26(1): $30-57$.

McCright, Aaron M., and Riley E. Dunlap. 2003. “Defeating Kyoto: The Conservative Movement's Impact on U.S. Climate Change Policy." Social Problems 50(3): 348-73.

Meyrowitz, Joshua. 1994. "The (Almost) Invisible Candidate: A Case Study of News Judgment as Political Censorship." In Controlling Broadcasting: Access Policy and Practice in North America and Europe, ed. Meryl Aldridge and Nicholas Hewitt. Manchester: Manchester University Press, 93-107.

Nadeau, Richard, Richard G. Neimi, and Timothy Amato. 1994. "Expectations and Preferences in British Elections." American Political Science Review 88(2): 371-383.

Nadeau, Richard, Richard G. Niemi, and Timothy Amato. 1996. "Prospective and Comparative or Retrospective and Individual? Party Leaders and Party Support in Great Britain." British Journal of Political Science 26(2): 245-58. 
Nadeau, Richard, Richard G. Niemi, David P. Fan, and Timothy Amato. 1999. "Elite Economic Forecasts, Economic News, Mass Economic Judgments, and Presidential Approval." Journal of Politics 61(1): 109-35.

Patterson, Thomas. 1994. Out of Order. New York: Vintage.

Price, Simon, and David Sanders. 1993. "Modeling Government Popularity in Postwar Britain: A Methodological Example." American Journal of Political Science 37(1): 317-34.

Robinson, Michael, and Margaret Sheehan. 1983. Over the Wire and on TV. New York: Russell Sage Foundation.

Rogers, Mark. 1994. Handbook of Key Economic Indicators. New York: Richard Irwin.

Sanders, David. 1996. "Economic Performance, Management Competence and the Outcome of the Next General Election." Political Studies 44(2): 203-31.

Sanders, David. 1999. “Conservative Incompetence, Labour Responsibility and the Feelgood Factor: Why the Economy Failed to Save the Conservatives in 1997.” Electoral Studies 19: 251-70.

Sanders, David. 2000. "The Real Economy and the Perceived Economy in the Popularity Functions: How Much Do Voters Need to Know? A Study of British Data, 1974-97.” Electoral Studies 19(2): 275-94.

Sanders, David, David Marsh, and Hugh Ward. 1993. "The Electoral Impact of Press Coverage of the British Economy, 1979-87." British Journal of Political Science 23(2): 175-210.

Shah, Dhavan V., Mark D. Watts, David Domke, David P. Fan, and Michael Fibison. 1999. "News Coverage, Economic Cues, and the Public's Presidential Preferences, 1984-1996." Journal of Politics 61(4): 914-43.

Shoemaker, Pamela J., and Tim P. Vos. 2009. Gatekeeping Theory. New York: Routledge.

Singer, Matthew M., and Ryan E. Carlin. 2013. "Context Counts: The Election Cycle, Development and the Nature of Economic Voting." Journal of Politics 75(3): 730-42.

Skewes, E.A. 2007. Message Control: How News is Made on the Presidential Campaign Trail. Lanham, MD: Rowman and Littlefield.

Soroka, Stuart. 2006. "Good News and Bad News: Asymmetric Responses to Economic Information.” Journal of Politics 68(2): 372-85.

Soroka, Stuart. 2012. “The Gatekeeping Function: Distributions of Information in Media and the Real World." Journal of Politics 74(2): 514-28.

Soroka, Stuart. 2014. Negativity in Democratic Politics: Causes and Consequences. Cambridge: Cambridge University Press.

Soroka, Stuart, Stephen Farnsworth, Lori Young, and Andrea Lawlor. 2012. "Event-Driven Environmental News in the U.S. and Canada." Electronic Media and Politics 1(10): 14357.

Soroka, Stuart, and Christopher Wlezien. 2010. Degrees of Democracy: Politics, Public Opinion and Policy. Cambridge: Cambridge University Press.

Stevenson, Randolph T. 2001. "The Economy and Policy Mood: A Fundamental Dynamic of Democratic
Politics?" American Journal of Political Science 45(3): 620-33.

Stevenson, Robert L., William J. Gonzenbach, and Prabu David. 1994. "Economic Recession and the News." Mass Communications Review 21: 4-19.

Stock, James H., and Mark W. Watson. 1989. "New Indexes of Coincident and Leading Economic Indicators." In NBER Macroeconomics Annual 1989, ed. Oliver Blanchard and Stanley Fischer. Cambridge, MA: MIT Press, 351-409.

Trumbo, Craig. 1995. "Longitudinal Modeling of Public Issues: An Application of the Agenda-Setting Process to the Issue of Global Warming." Journalism and Mass Communication Monographs 152: 1-57.

Vaccara, Beatrice N., and Victor Zarnovitz. 1978. "Forecasting with the Index of Leading Indicators." NBER Working Paper No. 244.

Van Der Brug, Wouter, Cees Van DerEijk, and Mark Franklin. 2007. The Economy and the Vote: Economic Conditions and Elections in Fifteen Countries. Cambridge: Cambridge University Press.

Wlezien, Christopher. 1995. "The Public as Thermostat: Dynamics of Preferences for Spending." American Journal of Political Science 39(4): 981-1000.

Wlezien, Christopher. 2005. "On the Salience of Political Issues: The Problem with 'Most Important Problem'.” Electoral Studies 24(4): 555-79.

Wlezien, Christopher, and Robert S. Erikson. 1996. "Temporal Horizons and Presidential Election Forecasts." American Politics Research 24(4): 492-505.

Wood, B. Dan, Chris T. Owens, and Brandy M. Durham. 2005. "Presidential Rhetoric and the Economy." Journal of Politics 67(3): 627-45.

Wu, H. Dennis, Robert L. Stevenson, Hsiao-Chi Chen, and Z. Nuray Guner. 2002. "The Conditioned Impact of Recession News: A Time-Series Analysis of Economic Communication in the United States, 1987-1996." International Journal of Public Opinion Research 14(1): 19-36.

Young, Lori, and Stuart Soroka. 2012. "Affective News: The Automated Coding of Sentiment in Political Texts." Political Communication 29(2): 205-31.

\section{Supporting Information}

Additional Supporting Information may be found in the online version of this article at the publisher's website:

Appendix A: Measuring Media Tone

Appendix B: Tests of Stationarity

Appendix C: Measures of the Past, Present and Future Economy

Appendix D: Past Studies of Media Coverage of the Economy 